\title{
Converting a King: The Jesuit William Crichton and King James VI and I
}

\author{
Thomas M. McCoog, S.J. \\ Fordham University \\ tmmccoog@gmail.com
}

\begin{abstract}
From the first encounter with King James vi of Scotland, the Society of Jesus believed in the possibility of his conversion. Such a religious transformation would reverberate beyond the northern kingdom and indeed beyond the British Isles. Finances and proposals were advanced to attain this goal. With noticeable encouragement from James in the 1590 as he positioned himself to ascend the English throne as Elizabeth's successor, many Catholics rallied to his cause. Once he had ascended the throne, he could cast caution to the proverbial wind and disclose his religious allegiance. Presented here are two memorials, both most likely written by the Scottish Jesuit William Crichton, on the possibility of James's conversion. The first can be dated circa 1580, at the very inception of the project; the second is post-Gunpowder Plot (1605) by which time nearly everyone had abandoned any hope in its successful completion. But Crichton, naively or optimistically, still insisted there was a chance.
\end{abstract}

\section{Keywords}

William Crichton - Robert Persons - James VI and I - religious conversion - English succession

\section{Introduction}

Would he or wouldn't he? Was it wishful thinking? A road not taken? Or careful manipulation of gullible Catholics? James's interest in Catholicism and Catholicism's interest in James are issues generally passed over quickly and superficially. Did anyone take the king's overtures seriously? In this article,

(C) THOMAS M. MCCOOG, S.J., 2020 | DOI:10.1163/22141332-00701002

This is an open access article distributed under the terms of the prevailing CC-BY-NC-ND 4.0 license. 
I shall consider one Jesuit, William Crichton (c.1535-1617), who despite everything still believed James to be susceptible to Catholicism's charms even after the Gunpowder Plot as seen in the two memorials here edited, the first from the early 1580 and the second from circa 1606.

To secure his Scottish legacy, Esmé Stuart (1542-83), seigneur d'Aubigny, left Dieppe for Leith in September 1579 with the blessing of Henry, duke of Guise (1550-88). By early October, he had gained the favor of his thirteen-year-old cousin, King James VI (1566-1625; r. [Scotland] 1567-1625 [England] 1603-25). Some suspected other motives behind d'Aubigny's visit: was he, they wondered, an agent of the Guises, secretly conniving for the restoration of Catholicism and the return of the imprisoned Mary, Queen of Scots (1542-87; r. 1542-67)? In March 1580, James granted d'Aubigny the earldom of Lennox after the incumbent had been persuaded to resign. Assisted by James Stuart (1545-95), later earl of Arran, Lennox negotiated the downfall of the Protestant former regent and pro-English James Douglas (c.1516-81), earl of Morton, in December 1580 and his execution in June 1581. To allay Protestant anxieties, in January 1581 following Morton's fall, King James repudiated popery in all its manifestations, and Lennox announced his conversion to Protestantism. Many, however, remained unconvinced. In August, d'Aubigny was created duke of Lennox, the only duke in Scotland. This may have been the promotion that changed Arran from friend to foe. ${ }^{1}$ As d'Aubigny increased his power and influence in Scotland, the Society of Jesus initiated its mission to England.

Robert Persons (1546-1610) first mentioned the Scottish King James VI in a letter to Alfonso Agazzari (1546-1602), rector of the English College (Rome), on November 17, 1580, circa five months after his arrival on the island. England, the Jesuit acknowledged, feared Scotland "whose king, now reaching maturity, they suspect may be more inclined to the Catholic Faith, now that a Frenchman of high station, d'Aubigny, who is a Catholic, has more influence with him than anyone else."2 Within a year, Persons was advocating Scotland as the linchpin on which the conversion of England and northern Europe depended, because the Scottish king and his imprisoned mother were the heirs of Queen Elizabeth I (1533-1603; r.1558-1603). Moreover, with the execution of

1 Rosalind K. Marshall, "Stuart, Esmé, First Duke of Lennox (c.1542-1583)," in Oxford Dictionary of National Biography [ODNB], ed. H. C. G. Matthew and Brian Harrison (Oxford: Oxford University Press, 2004); http://www.oxforddnb.com/view/article/26702 (accessed September 1, 2019).

2 The Correspondence and Unpublished Papers of Robert Persons, SJ., Volume 1:1574-1588, ed. Victor Houliston, Ginevra Crosignani, and Thomas M. McCoog, S.J. (Toronto: Pontifical Institute of Mediaeval Studies, 2017), 129. 
the earl of Morton, "some hopes have now begun to be conceived of this son of hers [Mary's] [...] if sufficient contact were made with him while he still gives evidence of great obedience to his mother and before he is confirmed in heresy, and also while the recent offences of the heretics are still in his mind." Among the various reasons Persons advances for James's personal conversion or, at least, his toleration of Roman Catholics, were devotion to his mother, security against obstinate heretics whose plots against him have been discovered by Catholics, and his hope of ascending the English throne. ${ }^{3}$ Persons sent an agent, the secular priest William Watts (d.1583), to Scotland to further the discussion. There Watts met Lennox, who introduced him to the king. By the time Persons received Watts's report, the Jesuit was in France and thus unable to participate personally, as requested, in future negotiations. Instead another English Jesuit, William Holt (1545-99), accompanied Watts back to Scotland in late December $1581 .{ }^{4}$ Henceforth James, despite many twists and turns in the tale, remained a "person of interest" for Roman Catholics, British and continental, and especially Jesuits. The two documents discussed in this article highlight Jesuit interest over a twenty-five-year period as the Society searched for the proper mediator.

\subsection{De missione in Scotiam pro conversione regis}

Persons complained of his annoyance that the Scots (presumably Jesuits) were not doing much to take advantage of this blessed opportunity to work for the king's conversion. ${ }^{5}$ Unbeknownst to Persons, another Jesuit was also advocating a mission. This anonymous (but endorsed as by William Crichton) undated document De missione in Scotiam pro conversione regis (Concerning a mission to Scotland for the conversion of the king) was most likely composed at this time. ${ }^{6}$

3 Persons to Claudio Acquaviva, superior general of the Society of Jesus, October 21, 1581, Houliston, Crosignani and McCoog, Correspondence of Persons, 220. Houliston makes it clear that this letter was written over a period of time. See pages 202-3. The "recent offences" probably concern James's conflict with the Kirk regarding James Boyd's successor as archbishop of Glasgow. The Duke of Lennox presented Robert Montgomerie, minister of Stirling, after Boyd's death in June. The General Assembly questioned Montgomerie personally and episcopacy in general. See David Calderwood, History of the Kirk of Scotland, ed. Thomas Thomson, 8 vols. (Edinburgh: Wodrow Society, 1842-49), 3:577-83.

4 See Thomas M. McCoog, S.J., The Society of Jesus in Ireland, Scotland, and England 1541-1588: "Our Way of Proceeding?" (Leiden: E. J. Brill, 1996), 178-80.

5 Persons to Acquaviva, October 21, 1581, Houliston, Crosignani and McCoog, Correspondence of Persons, 220.

6 This document can be found as Appendix 1. 
Internal clues suggest a date in the early 158 os. The author mentioned five Jesuits by name: Jean Lourin (c.1559-?), Ralph Allen (1547-88), Louis the subminster, Vincent Belandre, and Clément du Puy (1553-98). We can identify three. Ralph Allen, an Englishman, was, according to the author, at that time living in Tournon. He had entered the Society in either 1576 or 1577 and died before January 20, 1588. He was at Billom in 1584, and Avignon in $1587 .{ }^{7} \mathrm{Jean}$ Lourin, born in Avignon circa 1559, had entered the Society circa 1571. By 1587, he was stationed at the college in Paris. ${ }^{8}$ The Parisian Clément du Puy was born in 1553, entered the Jesuits in 1571, and died at Bordeaux on April 12, 1598. In 1578 , he was sent to study theology at the Jesuit university established by the Guises at Pont-à-Mousson in 1572. Because certain catalogues are not extant, we do not know when he left, but he was ordained and nominated provincial of Aquitaine by June $1588 .{ }^{9}$ Furthermore King James vi, born in 1566, was described as a "boy" (puer). The date seems therefore to be in the early 1580 . The memorial's attributed author William Crichton, to whom we shall return, had worked in the south of France from circa 1565 to 1581 and thus would have known personally Allen, Lourin, and du Puy. ${ }^{10}$

Many nobles, according to Crichton, both in Scotland and in France, deemed a mission for the conversion of James to be the most important enterprise that could be advanced for the benefit of religion in Scotland, Ireland, and England. Among them were Henry, duke of Guise, fervent Catholic and nephew of James's maternal grandmother Mary of Guise (1515-6o; r.1554-6o); James Beaton (1517-1603), archbishop of Glasgow and ambassador of Mary, Queen of Scots, in France; Claude Matthieu (1537-87), Jesuit provincial of France (and close associate of the Guises), and all Scottish Jesuits, at the specific request of James's mother Mary. Should this succeed, all subsequent endeavors would be easier and safer. James, the author contended, was more favorably disposed

The manuscript actually is difficult to decipher at this point. The city is either Turnonense (Tournon) or Tornacense (Tournai). I think the first is the better reading, because Allen entered the Society in Lyons in 1576 or 1577 and remained in the south of France. See Monumenta Angliae, ed. Thomas M. McCoog, S.J. (with László Lukács, S.J., for the third volume), 3 vols. (Rome: Institutum Historicum Societatis Iesu, 1992), 2:207.

8 Archivum Romanum Societatis Iesu [ARSI], Franc. 10, fols. $110^{\mathrm{r}}, 133^{\mathrm{r}}$. I thank Mauro Brunello at ARSI for tracking down this information, but he could not identify a date of death. Lourin is mentioned a few times in A. Lynn Martin's Henry III and the Jesuit Politicians (Geneva: Librairie Droz, 1973). According to Martin, Lourin was born in 1558, entered the Society in 1575, and died in 1634 or 1635 (257 but without primary documentation).

10 Thomas M. McCoog, S.J., "Pray to the Lord of the Harvest': Jesuit Missions to Scotland in the Sixteenth Century," The Innes Review 53, no. 2 (2002): 127-88, here 166. 
to Catholicism now because of recent conflicts with Scottish Protestants and his contact with the duke of Guise (presumably through the duke of Lennox). Who should undertake this mission remained problematic. Scottish Jesuitsand there were approximately twenty Scottish Jesuits at this time-were too well known because of their prominent families, e.g. Gordons, Hays, Crichtons. ${ }^{11}$ Their presence would not go undetected and therefore would arouse suspicion and generate opposition. Secular clergy "capable of conducting the mission with skill and determination" (qui dextre et fideliter omnia procurarent) were not easily identified. Thus, the author looked into non-Scottish Jesuits with a low public profile, mature and gracious conversationists, educated and intelligent, priests who would be welcomed by the king for these very traits. Despite his youth, the king had such a keen, penetrating intellect that superficial arguments would not win him over. Many judged Jean Lourin suitable. The author agreed that he had the requisite skills but questioned his prudence. Indeed, some thought that courtly life would be, in some unspecified way, his undoing - and life at court was essential for consistent access to the king. So, it was decided to send two other Jesuits to protect him against any danger and any temptation. The Englishman Ralph Allen was selected: his vocation was secure, and he was very edifying. Louis the subminister, at an unspecified Jesuit residence, and Vincent Belandre were under consideration. Either Louis or Vincent would be excellent, because the mission to support Lourin demanded virtue and prudence rather than intellectual skills. Their mission would be the exemplar for subsequent ones. Moreover, at court the Jesuits could offer solace, spiritual and otherwise, to Lennox and to George Gordon (c.1562-1636), earl of Huntly. The Catholic earl, whose uncle was the Jesuit James Gordon (1541-1620), was born $c .1562$ and had spent 1578 to postNovember 1580 in France. ${ }^{12}$ The young Huntly forged an enduring friendship with James. Huntly, Lennox, and other unnamed noblemen had sway at court. The author returned to Lourin's assets and liabilities. Having weighed both, the author decided against Lourin in favor of Clément du Puy. Hopes for the restoration of Catholicism within Scotland, England, and Ireland would increase because by law James had right of succession to their crowns. But not one of the Jesuits specified in the report traveled to Scotland.

The third reason advanced by Robert Persons for his departure from England in late summer of 1581 concerned a consultation with Archbishop Beaton

\footnotetext{
11 The number is based on calculations in McCoog, "Pray to the Lord of the Harvest."

12 J. R. M. Sizer, "Gordon, George, First Marquess of Huntly (1561/2-1636)," ODNB, http:// www.oxforddnb.com/view/article/11036.
} 
in Paris "about giving help to Scotland" at this most suitable time..$^{13}$ By the end of the year Claudio Acquaviva (1543-1615; in office 1581-1615), superior general of the Society of Jesus, ignoring the memorial's recommendation, assigned Crichton and Edmund Hay (c.1534-91), another well-known Scottish Jesuit, to the mission. Apparently, a lack of funds prevented Hay's departure. William Holt, Persons's substitute, and Crichton arrived in Scotland independently. On March 7, 1582, they met the duke of Lennox at Dalkeith. With promises of financial and military assistance from Spain and Rome to protect James against a possible Protestant uprising, Lennox formulated a proposal to restore Catholicism in the three kingdoms, to deliver Mary from imprisonment and to make out an arrangement (an "association") between her and her son regarding the Scottish crown and rights of succession to the English throne, ${ }^{14}$ and to allow Catholics banished for their faith to return home. A modest mission aimed at James's conversion in the face of Anglophile, Protestant opposition had expanded into a multi-front Counter-Reformation attack on England to dethrone Elizabeth and secure the dynastic rights of the Stuarts. With encouragement from Elizabeth, William Ruthven (c.1541-84), earl of Gowrie, captured James on August 22, 1582; Lennox was banished in January 1583, and Holt arrested in March. Despite diminished prospects, strategies, and negotiations initially for invasion and later for James's conversion and concessions for Catholics continued. ${ }^{15}$ For the next twenty years, Crichton devoted himself-almost consistently— to the Stuart cause.

2 William Crichton

A son of Patrick Crichton of Camnay, east Perthshire, William Crichton had studied at the universities of St. Andrews and Leuven. He and his cousin Edmund Hay accompanied the Dutch Jesuit Nicholas de Gouda (1515-65), sent by Pope Pius IV (1499-1565; r.1559-65) as papal nuncio to the court of Mary, Queen of Scots, in 1562. Crichton entered the Society in Rome on December 5 , 1562 , pronounced first vows on January 6, 1563, and was ordained priest circa

\footnotetext{
13 Persons to Acquaviva, October 21, 1581, Houliston, Crosignani and McCoog, Correspondence of Persons, 217.

14 On this still unexplored topic, see Susan Doran and Paulina Kewes, "The Earlier Elizabethan Succession Question Revisited," in Doubtful and Dangerous: The Question of Succession in Late Elizabethan England, ed. Susan Doran and Paulina Kewes (Manchester: Manchester University Press, 2014), 32-37.

15 McCoog, Society of Jesus in Ireland, Scotland, and England 1541-1588, 181-90.
} 
Pentecost (May 30) 1563. In 1565, he was sent to the south of France where he served as rector of different colleges and as vice-provincial of Aquitaine until 1581. A delegate to the general congregation that elected Acquaviva general of the Society in February 1581, Crichton discussed the possibility of a Scottish mission with the new general. The above-cited memorial may have been written for this meeting. By the end of the year, Crichton was on his way to Scotland and his new work. He returned to Rome in late spring/early summer of 1582 to bring Pope Gregory XIII (1502-85; r.1572-85) up-to-date, and to secure papal support for military ventures. He was in Rome when Lennox was overthrown. Lennox's removal closed and locked the back-door to England, and necessitated rejiggering the plans. But the door was unexpectedly reopened when James escaped from Gowrie in June 1583. James was now even more favorably disposed to Catholics and more hostile to Protestants whom he judged to be disloyal. Complete liberty for Catholics would follow as soon as he had fully protected himself and his kingdom against their wrath. ${ }^{16}$

In late August 1584, Crichton and another Jesuit, James Gordon, were captured by Dutch Calvinists at sea off the coast of Dieppe as they were sailing for Scotland. Gordon was released almost immediately, because the Dutch feared retaliation from his nephew George Gordon, earl of Huntly. Crichton was turned over to the English, transported to London, and imprisoned in the Tower of London for nearly three years. On Crichton, the authorities discovered outdated plans for the invasion of England. Nonetheless, he was released in May 1587 through the intercession of Sir Christopher Hatton (1540-91), described by Crichton as "a Catholic at heart."17 After visits to Paris and Rome, Crichton returned to Scotland in late 1587 to work for James's conversion and to secure his title to the English throne with the assistance of Spanish arms. ${ }^{18}$

The Treaty of Berwick signed on July 5, 1586, the Elizabethan government believed, ended the possibility of Scottish participation in any anti-English alliances. Because James might no longer be open to support alliances against Elizabeth, Spain now courted Scottish nobles, especially the Catholic earls (George Gordon, earl of Huntly; David Lindsay [1547?-1607], earl of Crawford;

16 Holt's letters from Edinburgh on March 20 [1584], April 1, 1584, April 7, 1584, and April 8, 1584, can be found in ARSI, Angl. 42 , fols. $49^{\mathrm{r}}-5 \mathrm{0}^{\mathrm{v}}$ (and translated in Narratives of Scottish Catholics under Mary Stuart and James VI, ed. William Forbes-Leith, S.J. [Edinburgh: William Paterson, 1885], 188-94).

17 "Memoirs of Father William Crichton, S.J.: 1584-1589," ed. John Hungerford Pollen, S.J., The Month 139 (1922): 317-24, here 324.

18 McCoog, Society of Jesus in Ireland, Scotland, and England 1541-1588, passim; McCoog, Monumenta Angliae, 3:56o-61; Mark Dilworth, "Crichton, William (c.1535-1617)," ODNB, http://www.oxforddnb.com/view/article/6702 (accessed September 1, 2019). 
Francis Hay [1564-1631], earl of Erroll; John Maxwell [1553-93], earl of Morton) and Protestants, such as Francis Stuart (c.1562-1612), earl of Bothwell, angered by the execution of Mary, Queen of Scots, on February 8, 1587. Crichton failed to convince James to convert or cooperate. Consequently, Morton initiated a rebellion in southwest Scotland and secured a port for the Spanish invaders. But the Spanish soldiers did not land; the rebellion was suppressed; and the rebellious earls conformed albeit reluctantly. The light slap on the hand did not satisfy the Elizabethan government, which demanded that James be more ruthless in his treatment of the earls. Among others Crichton lamented the failure of the Spaniards to land:

For many a day did we await the fleet of the Catholic King, with a longing, a loyalty not less than that with which Christ's coming was looked for by those who cried: "O that thou wouldst rend the heavens and wouldst come down. The mountains would melt away at thy presence." [Isaiah 64:1] But here there was no melting away of the mountains: they never even touched our shores, but fled, though none pursued. ${ }^{19}$

Crichton returned to the continent in the autumn of 1589 after the capitulation of the earls. Toward the end of October 1590, he arrived in Madrid. For the next two years he worked at court where he convinced King Philip II (1527-98; r.1556-98) that the Scottish Catholic earls sincerely supported the Spanish cause. Moreover, and more important for our concerns here, during this period Crichton had abandoned hope for James's conversion and recommended that Philip himself assume the crowns of England and Scotland and govern each through a viceroy. Perhaps we can label Crichton's loss of faith in James a politically expedient ploy to stir Philip into action, but the king did not go for the bait. In the spring of 1593, Crichton was in the Spanish Netherlands and once again arguing in favor of James. By January 1594, Crichton believed that James should be approached through the Catholic earls on whom the king depended to resist the kirk. Someone, and Crichton did not think it expedient that he himself be the agent, should be sent as a mediator. ${ }^{20}$ James Gordon returned

19 Hubert Chadwick, S.J., "Father William Creichton S.J., and a Recently Discovered Letter (1589)," Archivum historicum Societatis Iesu 6 (1937): 259-86, here 259-6o.

20 Francisco de Borja de Medina, S.J., "Intrigues of a Scottish Jesuit at the Spanish Court: William Crichton's Mission to Madrid (1590-1592)," in The Reckoned Expense: Edmund Campion and the English Jesuits. Essays in Celebration of the First Centenary of Campion Hall, Oxford (1896-1996), ed. Thomas M. McCoog, S.J., 2nd edn. (Rome: Institutum Historicum Societatis Iesu, 2007), 277-325. 
to Scotland with a large sum of papal money and promises of a monthly pension if James accepted Catholicism and protected Catholics. Upon landing at Aberdeen on July 16, 1594, he and his party were seized, and the money confiscated. But again, out of fear of his nephew, Gordon was not arrested. Indeed, the Jesuit sought out his nephew who, with the other Catholic earls, threatened the town's destruction if the prisoners were not liberated and the money restored. Subsequently, Huntly and his cohorts decided that the money would be better used to purchase arms and supplies for their military campaign. James Gordon and his Jesuit confrère William Murdoch (c.1539-1616) heard confessions and said Mass before the battle. On October 3, the earls defeated the Protestant forces of Archibald Campbell (c.1575-1638), earl of Argyll, at the battle of Glenlivet. Fear of or respect for their sovereign prevented them from following up the victory. By spring 1595, the earls of Erroll and Huntly were in exile on the continent. In May 1595, Crichton traveled to Cologne to meet James Gordon and the earls, each of whom believed that James's conversion was imminent. Different Scottish agents such as John Ogilvie of Pury (fl. 1590s) proclaimed James's fondness for Catholicism and cited examples of his kindness to individual Catholics. Crichton urged Pope Clement VIII (1536-1605; r.15921605) and Acquaviva to further the religious pilgrimage of this Catholic quasicatechumenate by endorsing his claim to the English throne. ${ }^{21}$ In 1595 or 1596, Monsignor Innocenzo Malvasia (1552-1612), papal agent in Flanders, recommended that Rome pursue a policy aimed at James's conversion in a memorial for Pietro, Cardinal Aldobrandini (1571-1621), secretary of state. Unfortunately, the appearance of R. Doleman's A conference about the next succession to the crowne of Ingland (n.p., 1594 [Antwerp, 1594]) impeded Crichton's and Malvasia's campaigns for James. The treatise's author(s) deprecated James's credentials with an insistence that Elizabeth's successor be a confirmed Catholic. Religious orthodoxy not royal blood was the principal criterion. Thus, the preferred candidate was the Spanish Infanta Isabella Clara Eugenia (1566-1633; r.1598-1621). Malvasia was invited to leave the Spanish Netherlands for a return to Rome, because his pro-Scottish sentiments were judged to be anti-Spanish. ${ }^{22}$

Without entering into the complicated question of the authorship of $A$ conference about the next succession to the crowne of Ingland let it suffice to note

21 See Thomas M. McCoog, S.J., The Society of Jesus in Ireland, Scotland, and England, 15891597: Building the Faith of Saint Peter upon the King of Spain's Monarchy (Farnham/Rome: Ashgate/Institutum Historicum Societatis Iesu, 2012), 239-43.

22 McCoog, Society of Jesus in Ireland, Scotland, and England, 1589-1597, 368-72; Thomas M. McCoog, S.J., "And touching our Society": Fashioning Jesuit Identity in Elizabethan England (Toronto: Pontifical Institute of Mediaeval Studies, 2013), 283-347. 
that Crichton believed that Robert Persons was the author. The Englishman explained that he would rather discuss the kingdom of heaven and not earthly realms, but the times demanded that Catholics formulate a clear policy. In brief, Persons could not support a heretical candidate or even one simply suspected of heresy. Persons would only endorse a candidate "most likely to be helpful in restoring and establishing the Catholic religion and the worship of God in our country."23

Crichton's increasingly aggressive promotion of James's credentials resulted in an unfortunate informal alliance with some English exiles, clerical and lay, who enthusiastically campaigned for the Scottish king and vehemently opposed English Jesuits, especially Persons and William Holt. ${ }^{24}$ The Spanish faction extolled the infanta's merits and denigrated James's. John Cecil (15581626), an English secular priest who merits further investigation, castigated James as he defended the Catholic earls and their secret negotiations with Spain. The king's suggestion that he would convert was nothing more than a sham to neutralize Catholic opposition to his succession. Could anyone believe in James's sincerity:

He hath with his own hand written books against the Catholic Religion. He hath made and published edicts. He hath banished many persons. He hath killed some. He hath conspired with the Queen of England, and hath followed her lead in everything. He hath married a Lutheran queen. He hath hardly seen or read a Catholic book in his life. He will not confer with or listen to any Catholic person on our side. All his relations, friends and familiars are heretics. How then is it possible that this man should become a Catholic all of a sudden? ${ }^{25}$

But James's hints increased after the appearance of Doleman's Conference, definitely post hoc and most likely propter hoc. Each royal wink and nod fanned Crichton's enthusiasm, but the conversion of Queen Anne of Denmark (15741619) was the clearest proof: Crichton acknowledged that he "attach[ed] much

23 Persons to Crichton, Seville, May 10, 1596, Archivum Britannicum Societatis Iesu, Coll P I 316, published with a few omissions in The Letters and Memorials of William Cardinal Allen (1532-1594), ed. Thomas Francis Knox (London: David Nutt, 1882), 381-83.

24 See McCoog, Society of Jesus in Ireland, Scotland, and England, 1589-1597, passim; McCoog, "And Touching Our Society," 302-6.

25 "Summary of Memorials Presented to the King of Spain, by John Ogilvy of Poury and Dr John Cecil. 1598," in Thomas Graves Law, "Documents Illustrating Catholic Policy in the Reign of James VI, 1596-1598," in Miscellany of the Scottish History Society, vol. 1 (Edinburgh: T \& A Constable, 1893), 37. 
weight to the conversion of the queen of Scotland; apart from her sex, nothing stands in the way of solid achievements." ${ }^{26}$ With reanimated optimism, Crichton refuted Cecil's remarks about James:

He is wise, he is learned, he is a Maecenas, and with his royall penne hath added immortall honour unto the Muses. I passe over his moderation, his ingenuytie, his moral vertues, which in hopes and blossoms are flowers of fruits to come, when it shall please God to temper his humane perfection with true pietie and religion. ${ }^{27}$

To Cecil's specific accusations, Crichton emphasized that the king had not written any tract against Catholicism and had only banished Catholics with good reasons. More important was James's protection of Jesuits William Holt and John Myrton (c.1555-1606), both of whom he saved from execution, and his reliance on Catholic advisers. Furthermore, James Gordon, the one Jesuit with whom James discussed theological and religious matters, did not judge him "an obstinate heretic." Crichton's defense of James, despite his subsequent disclaimer of authorship, influenced his transfer from the Spanish Netherlands to the south of France in late 1598. There, he and the Scottish William Chisholm (III) (1551-1629), bishop of Vaison, advanced James's efforts to secure papal and Catholic recognition. Unnamed Scots requested the Jesuit's and the bishop's presence in Scotland to facilitate James's conversion. Acquaviva hesitated, not simply, as Crichton suspected, because of Persons's opposition. Robert Abercrombie (1536-1613), superior of the Jesuits in Scotland and the priest who received the queen into the Roman Church, portrayed James differently:

The King is not only the cause of all the evils which have afflicted the country during the greater part of his reign, but continues to support, protect, and increase them. His language consists almost entirely of blasphemy or heresy. The single object of his ambition is the crown of England, which he would gladly take, to all appearance from the hand of the Devil himself, though Catholics and heretic ministers were all ruined alike, so great is his longing for this regal dignity.

He hates all Catholics, except so far as he can make use of them for the purpose of furthering his design of securing the English crown. Fear of Catholic ascendancy, or the hope of obtaining the favourite object of his

26 Crichton to [Oliver Mannaerts?], Louvain, February 3, 1598, ARSI, Germ. 178, fols. $40^{\mathrm{r}-\mathrm{v}}$.

27 This tract is included in Law's “Documents Illustrating Catholic Policy," 42. 
ambition, might some day make him a hypocrite; but only a great miracle of God's power, and an extraordinary inspiration, will ever make him a Catholic in reality.

He is a determined enemy of the Fathers of our Society, thinking that they are unfriendly to him, and that they oppose his claim to the crown of England. He considers them also causes of discord, sedition, and civil war. $^{28}$

No wonder Acquaviva hesitated. Who was to be believed? The pro-James Crichton or the anti-James Abercrombie? Neither was in Rome, but almost literally around the corner at the English College was Robert Persons, who had forsaken James years earlier. Given Persons's distrust and Abercrombie's qualms, the general's final approval of Crichton's mission, even with the condition that he be not the leader but simply a member of Vaison's entourage, is surprisingly bold. In late March, Elizabeth died, and James was proclaimed king of England. Crichton and Chisholm debated whether they should proceed to Edinburgh as planned or await the king's appearance in London. Acquaviva, meanwhile, suggested that they postpone their departure until they had confirmed reports of the state of affairs in London after James's accession. Complications threatened the mission. James Elphinstone (c.1553-1612), Lord Balmerino, recommended that Vaison delay departure, because the king had recently learned that the bishop had asserted in a treatise that any king who had abandoned the true faith should be stripped of his kingdom. ${ }^{29}$ Technically, he asserted, the bishop had committed the crime of lèse-majesté. Until this could be clarified, Balmerino suggested that the bishop remain in France. But Crichton? He was willing to cross the channel once he had received a travel permit from James. The Jesuit relied on his friends in James's entourage to obtain that for him. But again, complications arose: the king decided it was imprudent to grant a passport to a Jesuit because of all the edicts and proclamations against members of the Society. James promised that no harm would befall Crichton, but he could not issue a legal document. This rejection, subsequent reports about a conspiracy against James, and Crichton's exclusion from the presence of the French King Henry IV (1553-1610; r.1589-1610) triggered a downward spiral. Distressed,

28 ARsI, Angl. 42, fols. $15^{\mathrm{r}}-156^{\mathrm{v}}$. I quote from the section published in Forbes-Leith, Narratives of Scottish Catholics, 270-71.

29 The recent treatise was Examen confessionis fidei Calvinianae quam Scotus omnibus ministri Calviniani subscribendam et iurandam proponunt (Avignon, 1601). A French translation was published in Paris in 1603. I have not identified the offensive passage. 
deflated, and discouraged, Crichton returned to the south of France. The English Jesuits and the Scottish nobles that anticipated positive results from Crichton's journey to London were disappointed.

With more than a handful of memorials and petitions from Protestants and Catholics, James arrived in London on May 4, 1603, circa a week after Elizabeth's funeral. Expectations were high among the Catholics. There was a certain amount of initial leniency. ${ }^{30}$ Edward Bruce (1548-1611), Lord Kinloss, a Scottish member of the English Privy Council, met with Giovanni Carlo Scaramelli (fl. 16oos), Venetian secretary in England, on May 8. The councillor assured the secretary of James's gratitude to Pope Clement VIII for not excommunicating him or publicly endorsing a Catholic candidate and of his refusal to harass Catholics as long as they were quiet, discreet, and "decently hidden." But the secretary protested, Catholics expected more, specifically the restoration of Catholicism. "No! beyond a doubt this will never happen," the councillor protested. "Our bow which hitherto had two strings will have but one for the future; for he who wishes for the peaceable enjoyment of a kingdom must take care how he changes the religion in it, the smallest suspicion of such a thing is too serious a matter in a people firmly rooted in one faith."31 Despite proposals to buy religious tolerance or to include toleration on the agenda as the English and Spanish drafted their peace treaty, normal service seemed to have been renewed with James's expulsion of Jesuits and seminary priests on February 22, 1604 to protect his people "from being infected with superstitious opinions in matter of Religion, which are not onely pernitious to their owne soules, but the ready way and meanes to corrupt their duetie and allegiance."32 The new legislation and subsequent persecution did not deter James's supporters. The king, they explained, had to proceed carefully, had to find his feet in this unusual political context, but eventually all would be well. The Gunpowder Plot of November 1605 signaled the end of such optimism. On November 9, in an address to Parliament, the king carefully avoided a general condemnation of Catholics because of the treason of a few: "For although it cannot be

$30 \quad$ Regarding the expectations and confusion surrounding James's accession, see Thomas M. McCoog, S.J., The Society of Jesus in Ireland, Scotland, and England, 1598-1606: "Lest Our Lamp Be Entirely Extinguished" (Leiden: Brill, 2017), Chapter 3; Michael Questier, "The Politics of Religious Conformity and the Accession of James I," Historical Research 71 (1998): 14-30.

31 Calendar of State Papers and Manuscripts, relating to English Affairs, Existing in the Archives and Collections of Venice, and in Other Libraries of Northern Italy, ed. Rawdon Brown et al., 40 vols. (London, 1864-1947), 10:21-22.

32 Stuart Royal Proclamations, eds. James F. Larkin, C.S.V., and Paul L. Hughes, 2 vols. (Oxford: Oxford University Press, 1973-1983), 1:71. 
denied, That it was the onely blinde superstition of their errors in Religion, that led them to this desperate device; yet doth it not follow, That all professing that Romish religion were guiltie of the same." Yes, he concurred, only Catholicism considered it lawful "or rather meritorious (as the Roman Catholicks call it) to murther Princes or people for quarrel of Religion." Yet many Catholics were good, faithful subjects. ${ }^{33}$ James's refusal to condemn all Catholics revived the hope of at least one person that he was still convertible.

\subsection{Si doctorem haberet qui ei commonstraret}

The second memorial, untitled (I have provided a name), again anonymous and reproduced in Appendix 2, is in the hand of William Crichton. Written between the elevation of James Drummond (c.1580-1611) to the earldom of Perth in 1605 and the new oath of allegiance legislated in June 1606, the author highlighted James's aversion to Calvinism as a sign of his susceptibility to Catholicism. The king, the author admitted, was raised as a heretic. Nonetheless he abhorred Calvinism as practiced in Scotland: he dismissed the kirk's ministers as "disturbers of the realm" (reipublicae perturbatores) and consistently sought to curb their influence. The kirk's repudiation of episcopacy and its replacement with presbyteries and councils led to new legislation in 1584 , the so-called "Black Acts," which strengthened the beleaguered bishops now under the control of the monarch. The proliferation of presbyteries continued. In 1592, the Scottish Parliament confirmed this ecclesial form of government and approved the foundational Book of Discipline. Subsequently, James found ways to retain influence over and endure subservience to the kirk. ${ }^{34}$

Crichton claimed that the king's insistence on the ministers' submission to bishops would eventually overturn "the synagogue of Calvin" (Calvini synagogam) by depriving their presbyteries of any authority. The king's harassment and imprisonment of individual ministers, and the terms that he used in their description, e.g. "abominable plagues" (nefariis pestibus) that tormented the realm, demonstrated James's personal disdain for the ministers. Crichton cited as evidence the recent colloquium over which the king presided in London, an account of which was written by a "pseudo-dean."

The Hampton Court Conference, held in January 1604, pondered issues often raised by Protestant non-conformists in their petitions to the new king. William Barlow (d.1613), dean of Chester and later bishop of Lincoln, published

33 The speech can be found in James VI and I, Political Writings, ed. Johann P. Sommerville (Cambridge: Cambridge University Press, 1994), 152.

34 See William B. Patterson, King James VI and I and the Reunion of Christendom (Cambridge: Cambridge University Press, 1997), 1-13. 
The Summe and Substance of the Conference (London, 1604) allegedly with royal approval. This treatise, now criticized historiographically for a myopic interpretation, presented a king extremely hostile to the demands of the nonconformists and attributed to James the now classic defense of episcopacy: "No bishop, no king." Another royal declaration would have delighted Crichton: "I shall make them conforme themselves, or I wil harrie them out of the land, or else doe worse."35

Perhaps more important for Crichton's argument, James not only does not show similar hostility to Catholicism, but actually favored Catholics. Alexander Seton (1555-1622), appointed lord chancellor of Scotland in 1604 and a year later elevated to the earldom of Dunfermline, had studied under the Jesuits at the German College in Rome. "To his great harm," Crichton noted, Seton pretended to agree with the Calvinists (that is, he was a church papist), but the king knew well that he was a Catholic at heart. Although not mentioned by Crichton, the Jesuit William Holt was staying at the Seton residence and carrying correspondence from Alexander to his former teachers in Rome when he was captured in $1583 .{ }^{36}$ Other principal leaders in Scotland were Catholic: the above-mentioned George Gordon, earl of Huntly, Francis Hay, earl of Erroll (who was also chief constable) and others not named. James's eldest daughter Elizabeth (1596-1662), later known as the "Winter Queen," was entrusted to the care of Alexander, Lord Livingstone (d.1621) (after December, 1600 earl of Linlithgow) and his wife, Helen ( $f l$. 1590s), who was a Catholic and a sister of the earl of Erroll. Despite numerous threats and denunciations, the countess refused to attend Protestant services. The author knew this "with certainty" (rem mihi certo compertam scribo).

The author returned to the Hampton Court Conference to bolster his argument. At it the king clearly avowed that he had loathed the Calvinists since boyhood, because they repudiated what Roman Catholicism endorsed. At the end of the first day's session, according to Barlow's account, James admitted "since he was of the age of his Sonne, 10. years old, he ever disliked their [Calvinists'] opinions, as the Saviour of the world said, Though he lived among them

35 William Barlow, The Summe and Substance of the Conference (London, 1604), 82, 83. See also C. S. Knighton, "Barlow, William (d. 1613)," ODNB, http://www.oxforddnb.com/view/ article/1443 (accessed September 1, 2019); Patterson, King James VI and I, 43-48.

36 See Maurice Lee, Jr., "King James's Popish Chancellor," in The Renaissance and Reformation in Scotland: Essays in Honour of Gordon Donaldson, ed. Ian B. Cowan and Duncan Shaw (Edinburgh: Scottish Academic Press, 1983), 170-82; Maurice Lee, Jr., "Seton, Alexander, first earl of Dunfermline (1556-1622)," ODNB, http://www.oxforddnb.com.ezproxy.lib .gla.ac.uk/view/10.1093 (accessed September 1, 2019). 
he was not of them." In another section, the king acknowledged that he most disliked the Calvinists' total rejection of anything that had formerly been used by Catholics. The king ridiculed this type of reasoning: "By this argument wee might renounce the Trinity, and all that is holie, because it was abused in Poperie: (and speaking to Dr. Reyn. [John Reynolds (1549-1607)] merily) they used to weare hose and shooes in Popery, therefore, you shall, now, go barefoote."37 On the specific issue of the baptismal rite, James demanded that the sign of the cross be retained despite the strong objections of the non-conformists, and that the ministers wear squared hats and surplices. James did approve the bishops' vote in favor of the hats with the warning that anyone wearing such a hat found walking through Scotland would be stoned if the king were not with him. Moreover, the reason for the retention of the sign of the cross and the liturgical surplice was their ancient pedigree. ${ }^{38}$ Crichton's memory was playing tricks with him on the final observation regarding the conference. The king, if "I remember correctly" (si recte memini), quickly replied to a comment regarding a practice common at the time of St. Augustine (354-430) by stating clearly that the issue should not even have been raised "because he agreed with the ancient Church of Rome, which he knew was the Mother of all Churches" (se namque cum antiqua Romana Ecclesia, quam omnium ecclesiarum novit esse matrem, consentire). In the closest approximation to this sentiment that I could locate in the treatise, James was speaking not of Augustine but of Emperor Constantine (272-337): "What, quoth the King, and is it now come to that passe, that wee shall appeach Constantine of Popery and superstition; if then it were used, saith his Majesty, I see no Reason, but that still wee may continue it."39 But at Hampton Court, James did not refer to Rome as the "Mother of all Churches": he acknowledged "the Roman Church to be our Mother Church, although defiled with some infirmities and corruptions" in his speech to Parliament on March 19, $1604 \cdot{ }^{40}$

Crichton cited James's careful speech before Parliament after the "discovery of the last treasonable plot" (post detectam ultimam proditionem) in which he refused to condemn all Catholics, because he knew many virtuous members of that Church. Other members had been seduced by the doctrine that legitimized killing princes. Not one of them that "trewly know and beleeve the whole grounds, and Schoole conclusions of their doctrine, can ever prove

\footnotetext{
37 Barlow, Conference, 20, 72-73.

38 Barlow, Conference, 72, 74-75, 77.

39 Barlow, Conference, 72.

40 James VI and I, Political Writings, 139.
} 
either good Christians or faithful Subiects."41 Crichton explained that James knew nothing regarding the scholastic debate on tyrannicide and thus failed to distinguish between a "tyrant of the realm and a tyrant against the realm" (tyrannum regni, et tyrannum in regnum). ${ }^{42} \mathrm{He}$ considered Scholastic theologians enemies of kings, especially in their doctrine that a pope, on his own authority, could deprive any ruler of his/her kingdom. In his speech on March 19, 1604, James railed against the teaching that the pope had "an Imperiall civill power over all Kings and Emperors, dethroning and decrowning Princes with his foot as it pleaseth, and dispensing and disposing of all Kingdomes and Empires at his appetite."43

Crichton noted that James Drummond, created first Earl of Perth in 1605 and married to Isabel Seton (1593-1638), an "illustrious Scotsman about 26" (Drummond was born circa 1580), sent to Spain in the entourage of the English ambassador, ${ }^{44}$ publicly participated in the celebration of the Feast of Corpus Christi (June 17, 1604) as the ambassador himself watched from a window. James knew of this and did not reproach him for it. Crichton had received this information from a very credible nobleman.

Finally, the author doubted that anyone could make a justifiable claim that the king had consented to the execution of any Catholic on the basis of religion or presence at Mass. A comparable claim had sparked a small, intraJesuit debate a few years earlier. James Wood (d.16o1), laird of Boniton, was executed on April 27, 1601. He himself protested that he was in fact being martyred because he suffered for his faith. Robert Abercrombie endorsed the

41 James VI and I, Political Writings, 152.

42 The traditional distinction is tyrannus in titulo, that is an usurper, and tyrannus in regimine, an oppressor. The author has mistakenly labeled them tyrannus regni and tyrannus in regnum. See John Harty, “Tyrannicide," in The Catholic Encyclopedia, vol. 15 (New York: Robert Appleton Company, 1912), http://www.newadvent.org/cathen/15108a.htm (accessed September 1, 2019).

43 James vi and I, Political Writings, 140. See also Thomas H. Clancy, S.J., "English Catholics and the Papal Deposing Power, 1570-1640," Recusant History 6 (1961-62): 114-40, 205-27; 7 (1963-64): 2-10; Harro Höpfl, Jesuit Political Thought: The Society of Jesus and the State, c. 1540-1640 (Cambridge: Cambridge University Press, 2004), 314-38.

44 The precise identity of the ambassador remains unknown. Charles Cornwallis was the first resident ambassador and was sent to Spain in 1605. See Chris R. Kyle, "Cornwallis, Sir Charles (c.1555-1629)," ODNB, http://www.oxforddnb.com/view/article/6337 (accessed September 1, 2019). However, in May 1604 Charles Howard, earl of Nottingham, led an embassy to Spain for the ratification of the peace treaty (James McDermott, "Howard, Charles, second Baron Howard of Effingham and first earl of Nottingham (1536-1624)," $O D N B$, http://www.oxforddnb.com/view/article/13885 (accessed September 1, 2019). Drummond more likely traveled to Spain in Nottingham's entourage. 
laird's self-presentation. This Jesuit believed James vi to be the source of all evils and remarked that Boniton would not have been executed if he had not been a Catholic. On the other hand, Crichton exonerated James of any culpability: he suffered for crimes committed against his parents. At the request of Boniton's sisters, Jesuit Alexander MacQuhirrie $(c .1557-1606)$ had prepared a martyrological tract, but Crichton begged Acquaviva's intercession to prevent its appearance. It was never published. ${ }^{45}$ In 1604, the Catholic layman Robert Grissold (d.1604) and the secular priest John Sugar (1558-1604) were executed at Warwick, and the layman Laurence Bailey (d.1604) at Lancaster. Again James's supporters exonerated him with claims that he knew nothing about the sentences and executions until after the fact. Overzealous judges were to blame. James, in fact, preferred that the penal laws, although still on the book, remained unenforced ${ }^{46}$ These few signs were chosen by the author from the many that demonstrated clearly that the king was not entirely adverse to this path of salvation [i.e. Catholicism] (non esse omino alienum a via salutis). Yes, the author conceded in order to avoid different traps laid for him by the heretics, he unfortunately spoke of the pope in harsh, rash language. But all this could be remedied "if he had a teacher to show him the way."

Was James vi's flirtation with Catholicism serious? Was there ever a possibility, a probability, that he would abandon the kirk for the Roman Catholic Church? Would he as a young man under the influence of Lennox, Huntly, and other Catholics have taken such a step? Crichton and other Scottish Catholics and Jesuits believed the king to be personally susceptible to conversion if an appropriate teacher could be found. James, as Crichton noted, was young but not a fool. His religious instructor must be a courtier with theological acumen. The subsequent discussions, however, were concerned not with an apologia for Catholicism or the theological niceties that distinguished it from Calvinism but with diplomatic and military alliances to liberate Mary, Queen of Scots, to secure the Stuart succession, and to topple Elizabeth. Was this a missed opportunity? Later, in the 1590s, were the occasional unsubtle hints nothing more than skillful strategy and careful maneuvering to obtain Catholic support initially in his struggle with the Kirk and later in his campaign for the English throne?

45 See McCoog, Society of Jesus in Ireland, Scotland, and England, 1598-1606, Chapter 3.

46 McCoog, Society of Jesus in Ireland, Scotland, and England, 1598-1606, Chapter 5. 
Not even within the Society of Jesus was there consensus on James's sincerity: Robert Abercrombie, who had received Queen Anne into communion with Rome, denounced James as strongly as Crichton extolled him. Did James drop the pretense as soon as he attained his goal? Or did he realize somewhat gradually after his accession that the English political nation would not accept a Catholic monarch or legislated toleration? As he explained to Crichton, he could not flaunt the proclamations and the laws, but he could ignore them under certain conditions. Crichton, dissatisfied with these conditions, canceled his trip to James's court, but even after the Gunpowder Plot (1605) he remained convinced that James could still be won if the right agent was sent.

Crichton's second memorial was written after the Plot and before the antipapal oath of allegiance (16o6). To separate the sheep from the goats, Parliament introduced an oath of allegiance

that our sovereign lord King James is lawful and rightful King of this realm and of all other his Majesty's dominions and countries; and that the Pope, neither of himself nor by any authority of the church of See of Rome or by any other means with any other hath any power or authority to depose the King, or to dispose any of his Majesty's kingdoms or dominions, or to authorize any foreign prince to invade or annoy him or his countries, or to discharge any of his subjects of their allegiance or obedience to his Majesty, or to give licence or leave to any of them to bear arms, raise tumult or to offer any violence or hurt to his Majesty's royal person, state or government or to any of his Majesty's subjects within his Majesty's dominions. Also I do swear from my heart that, notwithstanding any declaration or sentence of excommunication or deprivation made or granted or to be made or granted by the Pope or his successors or by any authority derived or pretended to be derived from him or his see against the said King, his heirs or successors, or any absolution of the said subjects from their obedience, I will bear faith and true allegiance to his Majesty, his heirs and successors, and him or them will defend to the uttermost of my power against all conspiracies and attempts whatsoever, which shall be made against his or their persons, their crown and dignity, by reason or colour of any such sentence or declaration or otherwise and will do my best endeavour to disclose and make known to his Majesty, his heirs and successors, all treasons and traitorous conspiracies, which I shall know or hear of to be against him or any of them; and I do further swear that I do from my heart abhor, detest and abjure, as impious and heretical, this damnable doctrine and position, that princes which be excommunicated 
or deprived by the Pope may be deposed or murdered by their subjects or any other whatsoever. ${ }^{47}$

The oath of 1606 and the consequent controversy that pitted major Catholic theologians against Protestant divines and the king himself, for many, tolled the demise of talk or credible belief in the possibility of James's acceptance of Catholicism. James's Catholic supporters could mutter sperabamus like the disciples on their way to Emmaus. They had hoped.

47 Select Statutes and Constitutional Documents Illustrative of the Reigns of Elizabeth and James I, ed. G. W. Prothero, 4th edn. (Oxford: Clarendon Press, 1954), 259. 


\section{Appendix 1}

ARSI, Angl. 42, fol. $216^{\mathrm{r}-\mathrm{v}}$.

[fol. $216^{\mathrm{r}}$ ] De missione in Scotiam pro conversione regis

Multorum fuit opinio tam nobilium qui in Scotia degunt quam aliorum qui in Francia uti ducis Guysiani, oratoris Reginae Scotiae, P. Provincialis Franciae, et patrum Scotorum omnium qui sunt e Societate, nullam missionem in Scotiam posse esse utiliorem ea quae ad ipsum regem fieret, tam quod si ea bene succederet, omnes aliae missiones faciles essent futurae ac tutae, omnes immo in eadem sententia perseverant tum praesertim quod maior videtur esse in rege dispositio quam unquam prius, propter apertam eius aversionem a ministris et communicatione cum duce Guysiano. Sed quia non potest esse missio Scotorum e Societate quia sunt noti omnibus adversariis et ita non pateretur illis aditus nec reperiuntur seculares qui dextre et fideliter omnia procurarent, petuntur aliqui e Societate ad hoc idonei qui nec essent cogniti pro hominibus Societatis et propter aetatem et gratiam in conversando non essent regi ingrati et qui essent docti et acuti quia rex etsi sit puer est tamen tam acuti et faelicis ingenii, ut ab hominibus trivialibus non facile convincatur in suis erroribus. Multi iudicant Ioannen Laurinium habere talenta valde apposita ad hanc rem conficiendam sed quia de eius prudentia dubitatur ac timetur ne in aula vivendo dum regem cupit lucrari seipsum perderet, possent illi dari duo ex Societate qui his malis obviarent utpote P. Rodolfus Alanus Anglus qui modo est Turnonense (possible reading) et alius frater securus et bonae edificationis, ut possent esse, frater noster Ludovicus subminister aut Vincentius Belandre qui fortasse bonam operam navarent in hac missione nam prudentia et virtutibus erit ista res promovenda multo magis quam scientiis. Erit ista missio instar omnium. Nam ultra illud erit apud regem procurandum, erunt quoque iuvandi dux Lenoxius et Comes Huntleus et nonnulli alii proceres in aula a quibus pendet quasi tota regis authoritas et consilium. Quamvis in Laurinio reperiantur multa quae ad hoc negotium perficiendum sint idonea erit tamen timendum ne in illo desideretur prudentia et experientia quae in rebus agendis et conversatione cum aulicis esset necessaria. Ideo longe aptior ad hanc missionem mihi videtur esse P. Clemens Puteanus qui Mussiponti legit theologiam. Si ista missio habuerit successum, sicuti pro certo speratur, habiturum tunc erunt omnes aliae missiones et tutae et valde utiles ac optime sperandum de conversione regnorum Angliae, Scotiae et Hiberniae quae hunc sunt habitura heredem et regem si ius et equitas suum habuerint locum.

[fol. 216 ${ }^{\mathrm{v}}$ ] Endorsed: De missione Scotica. P. Creyton 


\section{Appendix 2}

ARSI, Angl. 42, fols. 261-63.

[si doctorem haberet qui ei commonstraret]

Jacobus Rex Magnae Britanniae in haeresi educatus, hoc tempore Calvini ministros tanquam Reipublicae perturbatores execratur, et quibus potest modia deprimit; name in Scotia psuedoepiscopus instituit, quibus vult ut ministri obtemperent, quod factum propediem funditus Calvini synagogam apud Scotos evertet, cum Calvinianum sit dogma, omnes Calvini ministros esse dignitate pares, et quod dissensiones omnes quae in ecclesia oriuntur a communi ministrorum conventu sedari debeant. Adempta est itaque ministrorum Calvini conventiculis, potestas omnis dicendi ius populo, et puniendi eos qui in leges quae vocant ecclesiasticas peccarunt.

Iden Rex sponte et nemine impellente, Calvini ministros vexat et persequitur, quorum aliquot superioribus annis in carceris coniici curavit, deque ipsis tanquam regnorum regumque nefariis pestibus, cum privatim tum publice loquitur, ut constat ex actis in Colloquio quodam, cui praefuit rex, et quod Londini a quodam pseudodecano est divulgatum.

Quod idem rex a Catholica religione non omnino abhorreat indicia sunt clarissima.

1. Regni Scoti cancellarium, qui pro regis officio fungitur, creavit Alexandrum Setonium, piae memoriae Gregorii 13 alumnus. Hic in seminario Romano studuit philosophiae et theologiae, et quamvis suo magno male simularit se cum haereticus consentire, rex tamen probe scit cum esse Catholicum.

2. Principes viri in Scotia, ut sunt Marchio de Huntlis, Comes Erroliae, qui est Scotiae constabularius, et alii non pauci, sunt Catholici, et nihilominus ipsi regi carissimi.

3. Regis filia natu maxima fuit educata a Comitissa de Lithguo, faemina primariam et prae caeteris Scotis in Catholica religione constante. [fol. 262] Nullis etenim sive regis precibus sive ministrorum minis et terroribus abduci potuit ut vel semel haereticorum syngogam adiret. Rem mihi certo compertam scribo.

4. In publico colloquio, cuius supra memini rex professus est, se postquam ex pueris excessit, hoc nomine aspernatum Calvini sectam, quod Calviniani ministri se ab omnibus quae Ecclesia Romana amplectitur abhorrere dixerint. 
5. Rex necquicquam reclamantibus Calvini ministris, constituit ut signum crucis in baptismi administratione retineatur utque pseudoepiscopi et ministri utantur pileis quadratis, et in publicis precibus, sacerdotum Catholicorum more, superpelliceis.

6. In eodem colloquio publico, cum dixisset nescio quia ministrorum aliquid in ecclesia esse usitatum, si recte memini, tempore D. Augustini, continuo subiecit rex, de iis quae illis temporis Ecclesia usurpabat non esse movendam quaestionem, se namque cum antiqua Romana Ecclesia, quam omnium ecclesiarum novit esse matrem, consentire.

7. In oratione quam idem rex, post detectam ultimam proditionem habuit ad regni Angliae ordines, negavit se condemnare Catholicos omnes, cum in ipsis multos inveniri viros probos sciret. Caeterum cum ignoret scholasticorum sententiam de occidendis tyrannis (non enim distinguit tyrannum regni, et tyrannum in regnum) invectus est in scolasticae theologiae professores, quod putat esse regum iuratos hostes; nam ipsi est persuasum quod theologi in scholis doceant summum Pontificem pro suo arbitratu regna quibus vult dare et auferre posse.

8. Comes Perthi illustris Scotus annos circiter 26 natus, in Catholica religione educatus, in Hispaniam cum Angliae legato profectus, in festus Corporis Christi, tanquam Catholicus, cum 40 nobilibus partim Scotis partim Anglis publicae supplicationi interfuit, ipso legato per fenestram spectante, at non propterea a rege suo, cui est carissimus, fuit reprehensus. Hoc accepti a viro nobili et erudito fide digno.

[fol. 263] 9. Difficile erit docere rege consentiente Catholicum ullum esse hactenus hoc nomine affectum supplicio, quod Catholicus fuerit, aut quod sacrasancto Missae sacrificio interfuerit.

Ex multis aliis luculentis quae adferri possunt indiiciis, haec pauca satis esse videntur ut intelligamus regem (qui ut sibi ab haereticorum insidiis caveat contra Summum Pontificem Christi Domini in terris vicarium multa pro dolor temere effutit) non esse omnino alienum a via salutis si doctorem haberet qui ei commonstraret.

Endorsed in a later hand: ?1606 